\title{
Prinsippet om fri bevisbedømmelse i et komparativt rettshistorisk og psykologisk perspektiv ${ }^{1}$
}

\author{
Forsker ph.d. Lisbeth Fullu Skyberg
}

Lisbeth Fullu Skyberg er cand.polit. fra 2001 ved Institutt for sosiologi og samfunnsgeografi, UiO, ph.d. ved Juridisk fakultet, UiO, 2019. Ansatt ved NKVTS og gjesteforsker ved NIFS, UiO.

Sammendrag: Artikkelen gir en kort gjennomgang av hvordan prinsippet om fri bevismuntlighet historisk utviklet seg i Norge, Frankrike og Tyskland. Forbindelsene mellom avskaffelsen av tortur, framveksten av menneskerettigheter og bevisrettens utvikling drøftes. Det går nærmere 100 år mellom at prinsippet lovfestes i henholdsvis Frankrike og Norge. Til tross for sosiale, kulturelle og historiske forskjeller er det konstellasjonen av fri bevisbed $\varnothing$ mmelse, bevismuntlighet, offentlig anklageprosess og lekmannsdeltakelse organisert som jury som på ulike tidspunkter fikk politisk gjennomslag i alle de tre rettsordningene. Sammen etablerte prinsippene grunnstrukturen i en strafferettslig beslutningsmodell. Framveksten av prinsippet om fri bevisbed ømmelse kan derfor vanskelig forstås alene, fordi begrunnelsene for dette prinsippet, både politisk og epistemologisk, var nær forbundet med de $\emptyset$ vrige prinsippenes begrunnelser. I dag er det særlig koblingen mellom direkte bevisførsel og fri bevisbed $\varnothing$ mmelse som problematiseres fra fagpsykologisk og beslutningsteoretisk hold. Dagens kritikk har klare paralleller til advarslene som ble fremmet i juridisk teori på midten av 1800-tallet, mot den endrede beslutningsmodellen som disse prinsippene etablerte.

Nøkkelord: fri bevisbedømmelse, rettshistorie, beslutningsteori, bias

\section{Innledning}

Anders Løvlie skriver i sin bok Rettslige faktabegreper fra 2014:

«I alle vestlige rettssystemer gjelder i dag et prinsipp om fri bevisbedømmelse. Prinsippet skal sikre at faktafastsettelse skjer på en måte som generelt fremmer sannhet, og angir hvordan man skal gå frem ved faktafastsettelse. [...] Med bevis forstås i alminnelighet noe som viser noe annet, og med bedømmelse siktes det gjerne til avveining av argumenter for og mot. Bevisbedømmelse er [en] form for intellektuell virksomhet som innebærer overveielse eller stillingtaken til bevis.» ${ }^{2}$

\footnotetext{
${ }^{1}$ Dette er et trykket manus av min prøveforelesning, avholdt ved Juridisk fakultet 18.06.2019, med den endring at kildehenvisninger er ført inn i fotnoter, og noen muntlige uttrykk er fjernet.

${ }^{2}$ Anders Løvlie, Rettslige faktabegreper, Oslo 2014, s. 270-272.
} 
Sitatet gir, i seg selv, ingen oversikt over den rettshistoriske utviklingen av prinsippet om fri bevisbedømmelse, men gjør det klart at prinsippets historie er en historie om imperialisme. Prinsippet framstår i dag som helt sentralt i vestlige modeller for rettslig beslutningstaking, og det er antatt å ha en sannhetsfremmende eller epistemologisk funksjon. Slik har det ikke alltid vært. Jeg vil i dag beskrive den utviklingen som skjedde på bevisrettens område fra midten av 1700-tallet og fram til slutten av 1800-tallet.

\section{Legal og fri bevisbedømmelse, stereotypisk framstilt}

\section{Et første utgangspunkt}

I den legale bevisteorien var bevisbedømmelsen underlagt lovbestemte føringer. Det forelå et nokså rigid system av bevisregler, og disse forhåndsbestemte reglene klargjorde hva slags type og mengde bevis som trengtes for domfellelse. Hva som - gitt Løvlies definisjon - kunne peke tilbake på noe annet og dermed fungere som bevis, var dermed i utgangspunktet strengt regulert. Et konkret uttrykk for legal bevisbedømmelse finner vi i Christian Vs Norske Lov av 1687, og den dansk-norske legale bevisretten hadde klare likhetstrekk med de samtidige kontinentale rettsordningene.

For de strengeste straffene trengtes det man kalte fullt bevis, og fullt bevis ble i hovedsak oppnådd enten gjennom den anklagedes tilståelse, formulert f.eks. i N.L. 1-15-1, eller gjennom to uavhengige vitnemål, formulert i N.L. 1-13-1. I den legale bevisbedømmelsen var beviskravet dermed konkretisert, og den «vissheten» som loven under ethvert system krever for å kunne dømme, var ikke å forstå som et abstrakt beviskrav som relaterte til den samlede bevissituasjonen i saken, som i vårt system. Beviskravet var, som påpekt av Magne Strandberg, en juridisk størrelse som fikk sitt innhold gjennom praktiseringen av de legale bevisreglene. ${ }^{3}$ Dette skulle sikre at den vissheten som utløste en domfellelse, fulgte av loven og ikke av dommerens subjektive vurderinger.

Under den frie bevisbedømmelsen ble på sin side dommerens vurdering frigjort fra slike forhåndsbestemte, lovregulerte krav til beviset selv. Vissheten som trengtes for domfellelse, var å finne i den enkelte dommers indre overbevisning, en ordning som gjerne betegnes som conviction intime. Beviskravet i denne modellen er abstrakt og knyttet til dommerens vurdering av hele bevissituasjonen, og ikke som i den legale begrenset til å beskrive tilstrekkelige og konkrete krav til

\footnotetext{
${ }^{3}$ Magne Strandberg, Beviskrav i sivile saker, Bergen 2008, s. 73.
} 
de enkelte bevis. Vissheten vil dessuten heller ikke kunne finnes eller påvises gjennom rene syllogistiske demonstrasjoner.

\section{Prinsippet kan vanskelig forstås alene}

Den amerikanske rettsepistemologen Larry Laudan har sagt at det straffeprosessuelle systemet er å forstå som en «epistemic engine», en sannhetsproduserende motor. ${ }^{4}$ Selv om prinsippet om fri

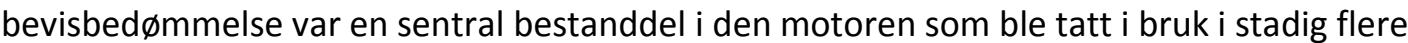
rettsordninger fra slutten av 1700-tallet, inngikk det systematisk i sammenheng med en del andre bestemte rettsprinsipper. Da prinsippet om fri bevisbedømmelse faktisk ble vedtatt i lovs form i Frankrike i 1791, i Tyskland fra 1848-1870 og i Norge i 1887, finner vi at den samme konstellasjonen av 1) fri bevisbed ømmelse, 2) bevismuntlighet, 3) offentlig anklageprosess og 4) lekmannsdeltakelse organisert som jury løftes fram som helt sentral i den rettslige beslutningsmodellen.

Til tross for forskjeller når det gjelder tid/sted/og kontekstuelle forhold da Frankrike, Tyskland og Norge innførte modellen, var det altså alle steder denne samlingen av rettsprinsipper som vant politisk gjennomslag. Når jeg senere skal komme nærmere inn på hvordan den offentlige og juridiske debatten foregikk i forkant av at prinsippet om fri bevisbedømmelse ble innført, vil det også framkomme at konstellasjonen av disse fire prinsippene ikke nødvendigvis var gitt. Det er likevel interessant at det altså var nettopp denne sammensetningen av rettsprinsipper som oppnådde tilstrekkelig politisk støtte til lovfesting. Dette betyr også at det er vanskelig å holde den framvoksende ideologien når det gjaldt hvordan bevisbedømmelsen burde skje, atskilt fra prinsippene om hva som burde utgjøre dommernes datagrunnlag og hvem dommerne burde være. Disse tre spørreordene - hvordan, hva og hvem - peker i sin tur videre i retning av en endret maktbalanse i samfunnet og en endret begrunnelse for straff.

\section{Ulike forklaringsmodeller for endringen som skjedde}

\section{Innledning}

Fri bevisbed $\varnothing$ mmelse vokste fram gjennom rettspraksis før prinsippet ble lovfestet, og det er åpenbart lettere å fastslå når lovendringen fant sted enn akkurat når og hvordan praksis endret seg. Når det gjelder hva som motiverte endringen av bevisretten, ser vi at forskningslitteraturen gjerne peker på to underliggende ideologiske strømninger. For det første skjer det en samtidig endring i den politisk-konstitusjonelle diskursen og forståelsen av forholdet mellom stat og borger. For det andre

\footnotetext{
${ }^{4}$ Larry Laudan, Truth, Error, and Criminal Law. An Essay in Legal Epistemology, Cambridge 2006, s. 2.
} 
skjer det en endring i den epistemologiske diskursen om hva som kunne utgjøre sikkert grunnlag for kunnskap, og på hvilken måte. Begge diskurser møtes imidlertid i en problematisering av den legale bevislærens bruk av tortur.

\section{Den politisk-konstitusjonelle diskursen}

Mange har pekt på at det fra antikken fantes forestillinger om menneskets stilling som var normativt begrunnet i naturen. Disse var imidlertid vage og hadde liten rettslig betydning, ifølge Dag Michalsen. ${ }^{5} \mathrm{~F} \varnothing \mathrm{r} 1750$ var naturretten først og fremst framtredende som filosofiske og politiske ideer, og bare sjelden skiftet disse ideene karakter og ble til virksom gjeldende rett i kraft av å være naturrett. Etter 1750 endret dette seg radikalt, sier Michalsen, og tilføyer at «intet er mer talende for denne forandring» enn den amerikanske uavhengighetsdeklarasjonen i 1776 og den franske i $1789 .^{6}$ Dokumentene medførte ikke først og fremst en ny sosial virkelighet, men de innebar en ny verden av rettslige muligheter, sier han. Ikke minst var det viktig at den franske erklæringen regulerte statens omgang med straff og slik - ifølge Michalsen - konstitusjonaliserte straffen, f.eks. gjennom artikler som uttrykte legalitetsprinsippet, prinsippet vedrørende lovers tilbakevirkende kraft og

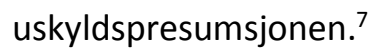

Den mest kjente boken som uttrykte dette endrede verdisynet, var Cesare Beccarias Om forbrytelse og straff, og ut fra ideen om samfunnskontrakten trakk Beccaria flere konsekvenser som begrenset statens legitime midler både ved undersøkelse av straffbare handlinger og gjennomføringen av straff. $^{8}$

\section{Behøves en psykologisk forklaringsmodell i tillegg?}

Den amerikanske rettshistorikeren Lynn Hunt peker imidlertid på at det ligger et begrunnelsesparadoks i den menneskerettslige tenkningen som kan peke mot behovet for en psykologisk forklaringsmodell. ${ }^{9}$ I alle menneskerettserklæringer, fra den amerikanske i 1776 til FNs i

\footnotetext{
${ }^{5}$ Dag Michalsen, Rett. En internasjonal historie, Oslo 2011.

${ }^{6}$ Ibid., s 267.

${ }^{7}$ Ibid., s 280.

${ }^{8}$ Ibid.

${ }^{9}$ Lynn Hunt, Inventing Human Rights, New York 2007.
} 
1948, har det stått sentralt at menneskerettighetene er universelle, umistelige og selvinnlysende. ${ }^{10}$ Jeffersons ord fra 1776 har blitt stående, påpeker hun:

"We held these Truths to be self-evident, that all Men are created equal, that they are endowed by their Creator with certain unalienable rights.. ${ }^{11}$

Hvordan denne uttalelsen skal forstås, har imidlertid vært gjenstand for debatt siden den ble uttalt, sier Hunt. Jefferson gjorde heller aldri noe forsøk på å forklare seg nærmere, noe som i og for seg også burde være unødvendig all den tid det var snakk om selvinnlysende rettigheter. Likevel kan verdenshistorien på mange måter forstås som en performativ selvmotsigelse hva gjelder budskapets riktighet, sier hun, og stiller to spørsmål: Hvis det er snakk om universelle, umistelige og selvinnlysende rettigheter, hvorfor blir de ikke universelt anerkjent? Og hva skjedde egentlig på midten av 1700-tallet som gjorde at disse ideene ble så sentrale at de kunne bli liggende til grunn for en konstitusjonalisering av straffen som gjennom forbudet mot tortur gjorde ende på den legale bevisbedømmelsen ${ }^{12}$

Hunt sier at for henne er det et spørsmål om å forklare hvordan ideene og kravene om bestemte rettigheter plutselig kunne begynne å spille en sentral rolle i samfunn hvor de tidligere ikke hadde vært vektlagt. Både hjerter og hoder må ha endret seg, mener hun, og påpeker at historikeres allergi mot psykologiske forklaringsmodeller har ført til en ensidig vektlegging av intellektuelle og politiske forklaringer. ${ }^{13}$

Anerkjennelse av menneskerettighetene avhenger av en empatisk identifikasjon mellom individer som, til tross for store sosiale forskjeller, forestiller seg at de er grunnleggende like. Dette forutsetter en evne til å føle empati på kryss av etablerte skillelinjer som klasse, rase, kjønn og nasjonalitet, og denne evnen måtte læres, mener Hunt. Læringen skjedde imidlertid ikke gjennom at folk leste politisk filosofi, sier hun, den skjedde gjennom utbredelsen av den epistoliske romanen, altså brev-

\footnotetext{
${ }^{10}$ Ibid., s 19.

${ }^{11}$ Ibid., s 15.

${ }^{12}$ Ibid., se også Lynn Hunt, «The Long and the Short Story of the History of Human Rights», Past \& Present, Volume 233, Issue I, 2016, s. 323-331. https://doi.org/10.1093/pastj/gtw044

${ }^{13}$ Ibid. Hunt, s. 329.
} 
og dagbokromanen på 1700-tallet. Poenget hennes kan kanskje illustreres med minneordet som Denis Diderot, forfatter av den første encyklopedien, skrev om Samuel Richardson, forfatter av brevog dagbokromanene Pamela og Clarissa, ved sistnevntes død i $1762 .{ }^{14}$ Om vi vil eller ikke, blir vi selv spillende en rolle når vi leser dine bøker, uttalte Diderot. Vi deltar i konversasjonene, anerkjenner og fordømmer, beundrer og indigneres. «Hvor mange ganger har jeg ikke, som barn som ser teater, tatt meg selv i å rope ut: ikke tro på ham, han bedrar deg! Gjør du dette er det ute med deg.» ${ }^{15}$

I løpet av et tidsrom på et par timer oppga Diderot å ha opplevd en lengre rekke av situasjoner enn selv et helt liv kunne by på.

Nettopp dette er viktig for Hunts poeng, fordi heltene og heltinnene i disse romanene muliggjorde identifikasjon og innlevelse med folk som ellers var sosialt utilgjengelige for de borgerlige leserne. ${ }^{16}$

\section{Epistemologisk endring}

De intellektuelle røttene til den legale bevisbedømmelsen finner vi i skolastisk filosofi, ifølge den finske rettshistorikeren Heikki Pihlajamäki. ${ }^{17}$ Her utgjorde bevis en form for genus, og ulike typer av bevis dannet et mer eller mindre intrikat system av underarter. Når ulike underarter med samme bevisverdi ble gruppert sammen, oppsto et gradert system, og det ble etablert et tredelt bevishierarki.

$\emptyset$ verst tronet fullt bevis, også kalt probatio plena, som i seg selv var ansett for å gi visshet og dermed ga grunnlag for domfellelse. ${ }^{18}$ På nivået under finner vi det ufullstendige eller utilstrekkelige beviset, probatio semiplena som utløste en mindre sikker form for viten, nemlig opinio hos dommeren, f.eks. i saker hvor man hadde ett, men ikke to vitner i en sak. Utilstrekkelige bevis kunne imidlertid adderes opp, slik at kravet om fullt bevis ble nådd. På det nederste nivået lå indisiebeviset som kun var i stand til å ut|øse en mistenksomhet, eller suspicio hos dommeren. Indisiebeviset var likevel viktig fordi det

\footnotetext{
${ }^{14}$ Denis Diderot (1762), Se f.eks. https://fr.wikisource.org/wiki/Éloge_de_Richardson

${ }^{15}$ Ibid., min oversettelse.

${ }^{16}$ Lynn Hunt, «The Long and the Short Story of the History of Human Rights», Past \& Present, Volume 233, Issue I, 2016, s. 329.

${ }^{17}$ Heikki Pihlajamäki, Evidence, Crime, and the Legal profession. The Emergence of Free Evaluation of Evidence in the Finnish Nineteenth Century Criminal Procedure, Stockholm 1997, s. 23.

${ }^{18}$ Ibid.
} 
etter hvert ble ansett tilstrekkelig til å igangsette tortur i et forsøk på å oppnå tilståelse, altså fullt bevis. ${ }^{19}$ Ifølge Magne Strandberg bygger bevisretten i NL på samme forutsetninger som den skolastisk funderte bevisretten. Hva som ble ansett som fullt bevis, var dessuten det samme i NL som hos skolastikerne. ${ }^{20}$ Den dansk-norske bevisretten var likevel preget av mindre raffinerte begrepsmessige sondringer, sier Strandberg, noe som gjorde dommernes skjønnsrom større.

I tillegg endret 1600-tallsrasjonalistene med sin metodologiske empirisme de klare skolastiske skillene mellom absolutt sikkerhet og mening, sortert i form av dikotomier som f.eks. scientia/opinio, sikkerhet/sannsynlighet og filosofi/retorikk. ${ }^{21}$ Kunnskap ble derfor i stadig større grad ikke forstått som et enten-eller, men som et kontinuum hvor fiksjon utgjorde den minst sikre delen av skalaen og moralsk sikkerhet den høyeste. Med dette ble kunnskap, eller det som kunne utgjøre et sikkert grunnlag for beslutninger, løst fra hva som logisk kunne demonstreres gjennom syllogismer. Denne mer generelle epistemologiske utviklingen fikk også betydning for bevisretten ved at den myket opp strengheten i det opprinnelige legale bevisbed ømmelsesregimet. ${ }^{22}$

Den amerikanske rettshistorikeren John Langbein hevder i boka Torture and the Law of Proof fra 1976 at de fleste framstillingene av hva som bidro til å avskaffe bruken av juridisk tortur / «judicial torture», dvs. «a mode of investigation into potential guilt, and not as a sanction», ${ }^{23}$ er å anse som eventyr, med hans begrep «fairy tales», bygget opp rundt følgende seks premisser: ${ }^{24} 1$ ) Juridisk tortur foregikk med uforminsket styrke inn på 1700-tallet. 2) På 1700-tallet ble det publisert verker, særlig av Beccaria og Voltaire, som avslørte torturens grusomhet. 3) Disse bøkene sjokkerte den europeiske samvittigheten og inspirerte store monarker til å avskaffe bruken av tortur. 4) Når torturen var avskaffet, sto europeerne rådville fordi mange forbrytelser ikke ville kunne pådømmes. 5) Andre former for press og tvang ble fors $\varnothing \mathrm{kt}$, som isolasjon og overtalelse til tilståelse. I tillegg ble en rekke straffer innført, f.eks. Iøgnstraff, altså fysisk avstraffelse for løgn, som i og for seg lignet på

\footnotetext{
${ }^{19}$ Ibid., s 48.

${ }^{20}$ Magne Strandberg, Beviskrav i sivile saker, Bergen 2008, s. 69.

${ }^{21}$ Heikki Pihlajamäki, Evidence, Crime, and the Legal profession. The Emergence of Free Evaluation of Evidence in the Finnish Nineteenth Century Criminal Procedure, Stockholm 1997, s. 45-46.

22 Ibid., s. 47.

${ }^{23}$ John Langbein, Torture and the Law of Proof. Europe and England in the Ancien Régime, Chicago [1976]/2006, s. 58.

${ }^{24}$ Ibid., s. 10.
} 
tortur, men som ikke ble klassifisert som det. ${ }^{25}$ 6) Til slutt innså europeerne at den romerskkanoniske bevisretten var ubrukelig uten tilgang til tortur, og gikk derfor over til et system med fri bevisbedømmelse.

Det er to grunner til å mistro slike framstillinger, ifølge Langbein. ${ }^{26}$ For det første forutsetter de en plutselig moralsk indignasjon og et raseri mot bruk av tortur samtidig som bruken av tortur jo faktisk hadde vært kjent i århundrer. Å stille spørsmålet om hvorfor klokkene ringte for torturen, avføder også spørsmålet om hvorfor folk fikk ører som hørte klokkene ringe. Så vidt jeg kan forstå, er det på dette punktet Hunt tilbyr en psykologisk forklaringsmodell, mens Langbein, som jeg vil komme til, presenterer en juridisk. Først vil jeg imidlertid presentere Langbeins andre grunn til skepsis. De tradisjonelle forklaringsmodellene vil ha det til at avskaffelsen av tortur inntraff før overgangen fra legal til fri bevisbedømmelse, noen steder nesten hundre år tidligere. Tankegangen er at 1700-tallet avskaffet torturen og 1800-tallet avskaffet den legale bevisbedømmelsen. Det har derfor vært antatt at det ikke er bevisretten som kan forklare avskaffelsen av tortur, men at avskaffelsen av tortur kan forklare endringen i bevisretten. ${ }^{27}$

Langbein snur imidlertid om på denne årsakssammenhengen. Den legale bevisretten mistet sin styrke på 1700-tallet, mener han. Parallelt med det gamle systemet ble det etablert et nytt, som fungerte etter prinsippet om fri bevisbedømmelse uten at det gikk under dette navnet, og det nye systemet fungerte ved siden av den romersk-kanoniske legale bevisretten. ${ }^{28}$

Den legale bevisretten ble brukt i enkle saker hvor det faktisk forelå fullt bevis. Men i saker som manglet to vitner eller tilståelse, frigjorde bevisretten seg fra den opprinnelige lærens krav om at bruk av tortur krevde en bevisstyrke på et halvt bevis. I middelalderen hadde det å holde ut tortur en frikjennende eller rensende virkning. ${ }^{29}$ Fra midten av 1600 -tallet kunne imidlertid bevisene som ga

\footnotetext{
${ }^{25}$ «Although judicial torture continued to be viewed as a mode of investigation, hence procedure, the practice and the legislation began to emphasize that torture was also a punishment, a poena, appropriate to a particular level of circumstantial evidence», John Langbein, Torture and the Law of Proof. Europe and England in the Ancien Régime, Chicago [1976]/2006, s. 58.

${ }^{26}$ Ibid., s. 11.

${ }^{27}$ Ibid., s. 11, se også side 61-69.

${ }^{28}$ Ibid., s. 61-69.

${ }^{29}$ Heikki Pihlajamäki, Evidence, Crime, and the Legal profession. The Emergence of Free Evaluation of Evidence in the Finnish Nineteenth Century Criminal Procedure, Stockholm 1997, s. 51.
} 
utgangpunkt for den opprinnelige torturen, danne grunnlag for såkalt ekstraordinær straff selv om den torturerte under torturen ikke tilsto. Med utgangspunkt i systemet med poena extraordinaria kunne den mistenkte fortsatt straffes, men ikke med en like streng straff som hvis han hadde tilstått under tortur. Med dette utviklet det seg et system som opererte etter løsere regler og med lavere krav til beviset, og dette systemet fungerte i tospann med det legale og mer rigide bevissystemet. Straffeteknisk viste det nye systemet seg å fungere effektivt, og Langbein argumenterer for at denne internjuridiske erfaringen var helt sentral for torturens avskaffelse. ${ }^{30}$

Endringen av bevisretten kan åpenbart forstås både politisk og rettslig, men litteraturen på området har oversett betydningen av den utviklingen som skjedde i rettssystemet selv, ifølge Langbein. Det ser også ut til at han mener at de politiske ideologene, f.eks. Voltaire, kunne framstå vel luftig for dem som hadde ansvar for straffesystemets praktiske gjennomføring. ${ }^{31}$ Voltaire kritiserte på den ene siden tortur for å være et upålitelig verktøy for å avdekke sannhet. Samtidig var han også skeptisk til den legale bevisrettens bruk av to vitner som fullt bevis, fordi de to vitnene kunne være skurker.

Voltaire overbød middelalderjuristenes regulering i sitt krav om sikkerhet for fellende kjennelser, ifølge Langbein, ved at han hevdet at hvis sannsynligheten for forholdet mellom skyld og uskyld var 100000 til 1, så måtte den anklagede frikjennes. En slik holdning var neppe egnet til å berolige statsmakter som var opptatt av å ivareta straffesystemets avskrekkende virkning, sier Langbein. ${ }^{32}$

Den kortfattede oversikten så langt kan kanskje først og fremst tjene til å underst øtte Pihlajamäkis påstand om at bevisretten, i likhet med straffen, må sees som en sosial institusjon som viser hen til en vev av sosiale og kulturelle motsetningsforhold, og at endringene i bevisretten er påvirket av så vel politiske, sosiale og epistemologiske endringer som utviklingen av den substansielle retten. ${ }^{33}$ Pihlajamäki peker imidlertid på at også utviklingen av den juridiske profesjon var av betydning for hvordan diskusjonen om bevisretten forløp i ulike rettsordninger.

\footnotetext{
${ }^{30}$ John Langbein, Torture and the Law of Proof. Europe and England in the Ancien Régime, Chicago [1976]/2006, s. $64-69$.

${ }^{31}$ Ibid., s. 68.

32 Ibid.

${ }^{33}$ Heikki Pihlajamäki, Evidence, Crime, and the Legal profession. The Emergence of Free Evaluation of Evidence in the Finnish Nineteenth Century Criminal Procedure, Stockholm 1997, s. 6.
} 


\section{Hvordan kom man fra a til å, altså fra bundet til fri bevisbedømmelse?}

\section{Frankrike}

I Frankrike var modellen for løsning av straffesaker på plass i 1791. Den var bygget rundt 1)

offentlighet, 2) bevismuntlighet, 3) fri bevisbedømmelse, 4) jury og 5) anklageprosess. I motsetning til i Tyskland, hvor en modell bygget rundt de samme prinsipper ble vedtatt først i Baden i 1848, for siden å finnes i de fleste tyske stater fra 1870, hadde man i Frankrike ingen stor rettsvitenskapelig debatt om prinsippet om fri bevisbedømmelse. Den straffeprosessuelle endringen kunne i Frankrike i hovedsak tilskrives opplysningstenkerne, ifølge Pihlajamäki, og at den franske revolusjonen hadde feid alle rester av legal bevisbedømmelse til side. ${ }^{34}$

Et svært klart uttrykk for idealet om regelfrigjøring av bevisbed ømmelsen finner vi i redegjørelsen som juristen Ole Munch Ræder, utsendt av det norske storting for å gjøre studier av andre lands juryordninger i perioden 1846-48, ga av den franske juryordningen rett etter revolusjonen. ${ }^{35}$ Både i England og Frankrike ble det regnet som et overordnet hensyn at bevisbedømmelsen skulle ledes av «Overbevisning alene» (conviction intime), sier Munch Ræder. ${ }^{36}$ Han gjengir så den franske dommer Bourguignons redegjørelse fra Manuel d'Instruction criminelle fra 1810 fordi «tanken i denne Lære er vistnok ganske træffende fremstillet» her. ${ }^{37}$ Pihlajamäki har senere hevdet at systemet knyttet til conviction intime gjennomgående var båret oppe av en idealisering av «the mystical capacity of lay jurors to arrive at correct decisions intuitively, trusting on their natural abilities and virtues only». ${ }^{38}$ Dette idealet kommer tydelig til uttrykk i Munch Ræders gjengitte sitat av Bourguignon. Som vi skal se, framstilles bevisvurdering her som en instinktiv prosess hvor sannheten, mer eller mindre av egen kraft, avslører seg selv når den umiddelbare bevispresentasjon setter bevisene i kontakt med bevisbedømmernes samvittighet.

\footnotetext{
${ }^{34}$ Ibid., s. 110.

${ }^{35}$ Ole Munch Ræder, Jury-Institutionen i Storbritanien, Canada og de forenede Stater af Amerika, Andet Bind, Christiania 1852.

36 Ibid., s. 540-541.

${ }^{37}$ Ibid., s. 542.

${ }^{38}$ Heikki Pihlajamäki, Evidence, Crime, and the Legal profession. The Emergence of Free Evaluation of Evidence in the Finnish Nineteenth Century Criminal Procedure, Stockholm 1997, s. 112.
} 
«[M]an lader dem see den Klagende, den Anklagede og dem, som have været Vidner til handlingen eller som kunne give Underretninger om de Omstendigheder, som have gaaet forud for og ere fulgte efter den. Debatten, som opstaar, bringer paa en Maade deres Samvittighed i Berørelse med Sporene, Indicierne og Beviserne. Naar disse ere tilstrækkelige, fremvirker Indtrykket, som de gjøre paa Jurymændenes Samvittighed, at de overbevises eller at Faktum bliver evident; og denne Overbeviisning danner sig naturligen hos enhver af dem uden andet Arbeide end en Smule Opmærksomhed, uden Anstrængelse og undertiden endog uafhængig af deres Villie. Det er saaledes, at vort Øie lader os dømme om Farverne, vort Øre om Lydene, vor Lugt om Parfumerne, uden at vi behøve at tage vor Tilflugt til Theorien om Lyset, om Lyden og Lugten.» ${ }^{39}$

Hvis vi da skal spørre, med Laudan, hva slags straffeprosessuell motor franskmennene hadde skrudd sammen i løpet av denne korte og opphetede tiden i landets historie, så tror jeg svaret må være en totakts dieselmotor. ${ }^{40}$

De muntlige og umiddelbart presenterte bevisene pumpes inn i motoren. Veivakselen, som får det hele til å skje, utgjøres av lekmenn som bare trenger en eneste omdreining før forbrenningen skjer. Systemet trengte ikke engang en tennplugg for å virke fordi møtet mellom de muntlige og umiddelbare bevisene og juryens sjette sans var selvantennende. Dette ser også ut til å ligge i kjernen av kritikken som denne straffeprosessuelle motoren siden har blitt til del. Pihlajamäki har sagt at hvis vi sammenligner den franske versjonen av fri bevisbed $\varnothing$ mmelse og conviction intime med den senere tyske modellens vekt på dommernes «Totaleindruck», framstår det franske systemet som ekstremt. ${ }^{41}$ Også nordmennene var skeptiske, både til juryordningen og franskmenn.

Enhver som bare hadde litt kjennskap til forholdene på den norske landsbygda, måtte innrømme at «man hos vor Gaardbrugerclasse i Almindelighed [ikke] træffer eller kan vente at træffe den almindelige Fordannelse eller den Aandsudvikling, som dog nødvendigvis maa kræves hos

\footnotetext{
${ }^{39}$ Bourguignon sitert fra Ole Munch Ræder, Jury-Institutionen i Storbritanien, Canada og de forenede Stater af Amerika, Andet Bind, Christiania 1852, s. 524-543, i petitavsnitt.

${ }^{40}$ Den som skulle ønske en kortfattet beskrivelse og illustrasjon av denne motortypen, kan f.eks. se https://no.wikipedia.org/wiki/Totaktsmotor\#/media/Fil:Arbeitsweise_Zweitakt.gif

${ }^{41}$ Heikki Pihlajamäki, Evidence, Crime, and the Legal profession. The Emergence of Free Evaluation of Evidence in the Finnish Nineteenth Century Criminal Procedure, Stockholm 1997, s. 111.
} 
Enhver, der skal betroes at afgjøre de forskjellige, ofte vanskelige Questioner, som forelegges Juryen», skrev Prosesslovkommisjonen nedsatt i $1853 .{ }^{42}$

Kommisjonen kom likevel med et lite tilleggsstikk til franskmennene fordi de ga uttrykk for at jury kanskje kunne være et godt alternativ i Norge, på sikt. I det norske folket så kommisjonen et potensial som den knyttet til en nasjonalromantisk idé om den «Den norske Nationalcharakteer». ${ }^{43}$ Nordmenn hadde et heldig stammeslektskap med engelskmennene, mente kommisjonen, som franskmennene dessverre manglet. En velfungerende juryordning hvilte nemlig ikke bare på dannelse, men også på folkekarakter. Selv om det i Frankrike ble stilt strengere krav til de edsvornes kapasitet, og dermed presumptive dannelsesnivå, enn i England, hadde den franske juryen ikke klart å holde seg fra en rekke «Udtskeielser» som den engelske - og også en framtidig norsk - jury kunne forventes å motstå pga. av deres «Sindighed», «Koldblodighed» og "Alvor». ${ }^{44}$

\section{Tyskland}

Den formelle overgangen fra legal til fri bevisbedømmelse kom flere tiår senere i Tyskland enn i Frankrike, og den falt også sammen med dannelsen av en rettsvitenskapelig profesjon. Dette bidro til at spørsmålet om bevisteori ble et sentralt rettsvitenskapelig emne.

Jeg vil her oppholde meg ved det Pihlajamäki og den nederlandske rettshistorikeren Ronnie Bloemberg beskriver som den modellen som hadde en viktig brobyggende funksjon mellom legal og fri bevisbed $\varnothing$ mmelse i Tyskland, ${ }^{45}$ nemlig den såkalte negative bevisteorien som inkluderte trekk fra begge modeller. I den negative bevisteorien sto det sentralt at en fellende dom ikke kunne avsies uten dommernes indre overbevisning om skyld. Overbevisning alene var likevel ikke nok. I tillegg til overbevisning måtte bevisene i saken oppfylle visse minimumskrav. Den tyske rettsteoretikeren Anselm Feuerbach begrunnet i 1813 dette dobbeltsporet med at mens sannheten ligger i saken, ligger overbevisningen i mennesket, og fordi mennesker ofte ser det som ikke er, eller overser det

42 Proceslovcommisionen av 1853, Om Forandringer i Straffeproseceslovgivningen med eller uden Jury. Betcenkning. Andet Bind, Første Deel, Christiania 1856, s. 204.

${ }^{43}$ Ibid.

${ }^{44}$ Ibid, s. 191-193.

${ }^{45}$ Heikki Pihlajamäki, Evidence, Crime, and the Legal profession. The Emergence of Free Evaluation of Evidence in the Finnish Nineteenth Century Criminal Procedure, Stockholm 1997, og Ronnie Bloemberg, «The development of the German criminal law of evidence between 1750 and 1870: From the system of legal proofs to the freie beweiswürdigung, part I», Journal of European History of Law 2018, volume 9, issue 1, s. 2-24. Artikkelens del to finnes i tidsskriftets påfølgende nummer, side 2-22. 
som er, fester de seg like gjerne ved feil som ved sannheten. ${ }^{46}$ Fordi erkjennelseskildene som retten bygde på, også kunne lede til feilaktige vurderinger, mente Feuerbach at det måtte oppstilles tilleggsbestemmelser, utover overbevisningskravet, for å sikre avgjørelsenes godhet.

Tyskernes straffeprosessuelle sannhetsmotor i denne perioden kan derfor kanskje best beskrives om en firetakts bensinmotor. ${ }^{47}$ Flere ting skiller den tyske motoren fra den franske. Bevisene pumpes riktignok inn til venstre, men veivakslingen består av fagdommere, og disse måtte ikke bare gå én, men to runder før sannheten om faktum kunne presses ut til høyre. I tillegg trengte denne motoren, i form av de presiserte minimumskravene til bevisene, en tennplugg for i det hele tatt å antenne, illustrert av at dommernes nakne overbevisning i seg selv ikke var nok.

\section{Norge}

\section{En diskusjon med utgangspunkt i rettspraksis}

Jeg vil bruke litt mer tid på å diskutere utviklingen i Norge, og det vil komme fram at man i Norge på 1800-tallet på ulikt grunnlag distanserte seg fra begge de to ovenfor presenterte modeller for bevisvurdering.

Når det gjelder den politisk-konstitusjonelle innflytelsen fra opplysningstenkningen, kommer denne klart til uttrykk både i det Adler-Falsenske grunnlovsutkastet og i grunnloven fra 1814. I sistnevntes $\S$ 96 første ledd ble legalitetsprinsippet hjemlet, i andre ledd finner vi forbudet mot såkalt pinlig forhør.

Det finnes ulike synspunkter på hvor fri eller bundet bevisbedømmelsen var i Norge før den formelt ble lovfestet med juryloven i 1887. Men alle ser ut til å være enige om at prinsippet om fri bevisbed $\varnothing$ mmelse gradvis vokste fram gjennom rettspraksis, slik at lovendringen fra 1887 ikke hadde så stor betydning når det kom til måten bevisbedømmelsen skulle skje på. Slik beskrives det av Francis Hagerup på slutten av 1800-tallet, og slik har det i vår tid blitt beskrevet både av Lars Björne og Dag Michalsen. ${ }^{48}$ Anton Martin Schweigaard skriver også, i sin Proces fra 1849, at lovens taushet

\footnotetext{
${ }^{46}$ Anselm Feuerbach, Betrachtungen über das Geschworen Gericht, Landshut 1813, s. 135.

${ }^{47}$ For en illustrasjon, se f.eks. https://snl.no/forbrenningsmotor

${ }^{48}$ Francis Hagerup, Den norske civilproces, bind 1, Kristiania,1895, s. 377; Lars Björne, Brytningstiden. Den nordiska rättsvetenskapens historia, del II 1815-1870, Stockholm, 1998, s. 403, Dag Michalsen, Norsk rettstenkning etter 1800. Tolv studier, Oslo 2013, s. 140.
} 
om indisiebevis ikke var blitt tolket av $\mathrm{H} \varnothing$ yesterett som et prinsipielt forbud mot å vektlegge indisier, men at kravene til indisienes styrke i «criminelle saker» i så fall måtte bli så strenge at de sjelden kunne anses oppfylt. ${ }^{49}$ Han viser likevel til en sak fra 14. april 1832 og en sak fra 25. november 1848 hvor Høyesterett på bakgrunn av det Schweigaard kalte ublandet indisiebevis, hadde avsagt dødsstraff.

På bakgrunn av dette kunne man også tenke seg at domstolen tross alt var såpass fristilt at det ville være lett å overkomme det Michalsen kaller de konstitusjonaliserte kravene til idømmelse av straff. Jeg vil begynne med å drøfte to saker fra norsk rettspraksis som kan danne utgangspunkt for diskusjonen om hvor fritt man sto i Norge, og hvordan man sto fritt, på midten av 1800-tallet.

Den første saken er å finne i Rt-1845-697. Saken gjelder en herr Ytterborg fra Christiania som hadde bedt politiet utføre den refselsesretten han lovlig hadde overfor sitt tyende, i dette tilfelle tjenestedrengen Anders Halvorsen som 17. mai hadde stukket av og gått på fylla og ikke kommet tilbake før langt utpå ettmiddagen påfølgende dag. Politiet etterkom Ytterborgs ønske og tok derfor Halvorsen med seg på politikammeret og ga ham 16 slag på ryggen med en «Tougtamp». Det etterfølgende problemet for politiet i denne saken startet med at Halvorsen ble syk av refselsen, som påførte ham det som i dommen benevnes som «den verste af alle Sygdomme - Sindsvaghed». Halvorsens brødre anmeldte derfor politimesteren, som i politiretten ble ilagt erstatningsansvar for hendelsen. Høyesterett opprettholdt siden dommen. Sentralt i argumentasjonen er at når politiet utførte Ytterborgs refselsesrett, på politikammeret, så forandres aldeles «Hustugtens væsen og giver den Charakter af en offentlig Straf - og det af det mest krænkende Slags». Hendelsen ble slik sett som et mulig brudd på Grl. § 96 første ledd. Dommen fikk også oppmerksomhet både i Morgenbladet, som hyllet avgjørelsen, og i Den Constitutionelle, som kritiserte den. ${ }^{50}$ Poenget her er at den borgersikkerheten som var hjemlet i Grl. § 96 i denne saken, ble trukket opp som en skranke for statens maktutøvelse.

Argumentasjonen i saken fra 1845 gjør imidlertid at en sak som dukker opp fem år senere, og som gjengis i Rt-1850-636, framstår som forunderlig. Her skulle Høyesterett vurdere en anke fra Amund Hansen Sætherholen som var blitt dømt til 8 års straffarbeid for simpelt og grovt tyveri, blant annet

\footnotetext{
${ }^{49}$ Anton Martin Schweigaard, Proces, bind I, Christiania 1849, s. 786-787.

${ }^{50}$ Nils Rune Langeland, Høgsterett i norsk historie 1814-1905. Siste ord, Oslo 2005, s. 145.
} 
fordi han sammen med flere hadde stjålet noen matvarer fra et stabbur. I første omgang ble Sætherholen frikjent, står det i dommen, fordi han etter først å ha tilstått tyveriet besvarte alle spørsmål med «Jeg veed ikke», og «for $\varnothing$ vrigt forholdt sig paa en saa ualmindelig Maneer, at saa vel Districtslægen som Retten antoge, at han manglende sin fulde Forstand $\gg .{ }^{51}$ Etter å ha blitt løslatt og sendt hjem meldte hans kone fra til politimesteren at den frikjente var hjemme og at han følte seg bedre. «Lensmanden, som under Angjældenes hele Arresttid, havde haft Mistanke om, at hans [Sæterholens] Atfærd var overlagt, blev herved bestyrket i sin Mistanke», kan vi lese i dommen. Etter å ha forlatt bygda for å jobbe kom Sætherholen utpå høsten tilbake til bygda, og lensmannen leverte da en innberetning til « $\emptyset$ vrigheden om sine lagttagelser», hvilket førte til at Sætherholen ble hentet inn til arresten på nytt. I arresten påsto han at han led av hodepine og dessuten ikke kunne huske hva han hadde holdt på med i årene 1847 og 1848, som var tidspunkt for de aktuelle forbrytelsene. Sætherholen ble dømt, først av Stiftsoverretten, siden opprettholdt av Høyesterett. Det overraskende ved denne avgjørelsen er ikke først og fremst resultatet. I avgjørelsen nevnes flere indisiebevis, og det diskuteres også at Sætherholens første tilståelse kan ha hatt betydning, om ikke som fullt bevis, så i alle fall som indisium. Det mystiske med denne avgjørelsen er at det etter siste punktum i Høyesteretts avgjørelse er satt inn en asterisk, en stjerne, som en fotnote, og i denne er tatt inn en legeerklæring som jeg her vil sitere i sin helhet.

«I vedkommende Læges Erklæring indeholdes Følgende, om hvorledes han har $\varsigma \varnothing$ gt at styrke Angjældendes Hukommelse: 'Den 10de Marts, da jeg igjen var hos ham (Angjældende) og spurgte om hans Befindende, svarede han, at han for Øieblikket var rask, men at Hovedpinen af og til indfandt sig, og negtede han fremdeles at kunne erindre, hvorledes han havde tilbragt Aarene 1847 og 1848. Baade fordi et kraftigt deriverende Middel vilde være ham tjenligt, hvis han virkelig led av Hovedpine, som omforklaret, men fornemmelig for om muligt at faae ham til at gaae til en oprigtig Bekjendelse om sin Sundhedstilstand, havde jeg medtaget et Brændejærn og forevisende ham dette tilkjendegav jeg, at jeg vilde brænde ham i Nakken for at befrie ham fra hans Hovedpine og styrke hans Hukommelse. 'Det behøves nok ikke', sagde han; men paa Lensmandens gjentagne Formaning til Angjældende, medens jeg opvarmede Jærnet, om at han burde erkjende at have anstillet sig sindsvag i den Tid, han sad arresteret, svarede han, at han 'ikke kunde sige Andet, end hvad der var sandt'. Uagtet jeg havde 3 stærke Karle til holde han, foer han alligevel op af Stolen, idet jeg anvendte det hvidglødende Jærn og ytrede: 'At saadant kunde han ikke tillade'..152

\footnotetext{
${ }^{51}$ Rt-1850-636 s. 637.

${ }^{52}$ Rt-1850-636 s. 639.
} 
Med dagens $\varnothing$ yne framstår dette som et eklatant brudd på den dagjeldende Grl. § 96.2 om forbud mot pinlig forhør. Bestemmelsen eller legeerklæringen drøftes likevel overhodet ikke i dommen. Den er heller aldri oppe til diskusjon i de offentlige voteringene fra $\mathrm{H} \varnothing$ yesterett, slik disse er gjengitt av sakens to referenter. ${ }^{53}$

Runar Torgersen har beskrevet Grl. § 96.2 som en beviservervsnorm. ${ }^{54}$ Selv om den som sådan kan ramme annet press enn den rene tortur, inneholder den ikke noen regulering av bevisforbud, mener Torgersen, og påpeker at den har «heller aldri vært vurdert slik». ${ }^{55} \mathrm{H} \varnothing y e s t e r e t t$ vektlegger da heller ikke legeerklæringen i sin avgjørelse, men kritiserer heller ikke lensmannens framgangsmåte. Saken reiser slik flere spørsmål enn den gir svar på. Fem år tidligere framsatte Høyesterett Grl. § 96.1 som en skranke mot statens maktut øvelse. I Rt-1845-697 ble volden som ble ut $\varnothing v d$, forstått som refselse, og selv om refselsesrett forelå, kunne den altså ikke overdras politiet uten å endre karakter slik at den kom i potensiell grunnlovsstrid. Ifølge Nils Rune Langelands høyesterettshistorie, som ikke omtaler denne siste saken, var vold på denne tiden utbredt, men underdefinert som abstrakt begrep. ${ }^{56}$ Kanskje kan volden som brenningen i saken fra 1850 utgjorde, ha blitt forstått som en form for medisinsk behandling? En slik tolkning virker likevel som en ren forkledning i og med at den skjer i arresten, med lensmannens tilstedeværelse og stadige oppfordring til den arresterte om å fortelle det som det var. Kanskje vektla ikke advokat Rygh, som førte saken for Sætherholen, legeerklæringen i sin prosedyre? Det eneste vi vet om Rygh, ut fra saken alene, er at høyesterettsdommer Lange, ifølge de muntlige voteringene, mente at Rygh hadde satt salæret sitt vel høyt, «men dog gjør jeg her intet Forslag», uttalte han. ${ }^{57}$ Det vi imidlertid kan være relativt sikre på, er at legeerklæringen må ha inngått i bevismaterialet for $\mathrm{H} \varnothing$ yesterett, siden den i Retstidende er vedlagt dommen - og dermed framstår det også som pussig at den av Høyesterett får inngå ukommentert.

Hvor fritt sto vi da egentlig i Norge på midten av 1800-tallet? Hadde vi særlig gode muligheter til en effektiv strafferettspleie - gjennom å være sikret anledningen til å idømme selv dødsstraff på

\footnotetext{
${ }^{53}$ Referat fra Høyesteretts muntlige voteringer er tilgjengelig ved Riksarkivet; de ulike referentenes nedtegnelser er systematisert på rekke $\mathrm{A}$ og $\mathrm{B}$.

${ }^{54}$ Runar Torgersen, Ulovlig beviserverv og bevisforbud i straffesaker, Oslo 2008.

55 Ibid., s. 68.

${ }^{56}$ Nils Rune Langeland, Høgsterett i norsk historie 1814-1905. Siste ord, Oslo 2005.

${ }^{57}$ Muntlig protokoll fra Rt-1850-636, rekke A.
} 
bakgrunn av indisier samtidig som vi kunne fors $\varnothing$ ke å framtvinge tilståelser ved bruk av vold $\mathrm{i}$ et fors $\varnothing \mathrm{k}$ på å sikre uangripelige avgjørelser gjennom fullt bevis?

Et juridisk-teoretisk bilde på forholdet mellom frihet og binding i bevisbedømmelsen får vi hos Prosesslovkommisjonen av 1853.

\section{Prosesslovkommisjonens turnering av frihet og binding}

Kommisjonen tok i sin vurdering stilling til tre spørsmål, nemlig om bevispresentasjonen i straffesaker burde være muntlig og umiddelbar, om bevisbedømmelsen burde være fri, og om alvorlige straffesaker burde avgjøres av jury. Kort fortalt besvarte kommisjonen alle disse spørsmålene med et nei.

Bevispresentasjonen burde ikke være muntlig og umiddelbar, fordi en slik presentasjonsform var unødvendig og/eller uheldig. Enten kunne den informasjonen dommerne fikk gjennom direkte bevisførsel, la seg nedtegne i skriftlige bevisakter som fulgte saken, eller også var det snakk om en type informasjon som måtte antas å forstyrre dommernes dømmekraft uten at det engang lot seg protokollere hva slags innflytelse beviset/informasjonen hadde hatt:

«Det maa ligeledes erindres, at de Mødendes personlige Fremtræden, Minespil m.m., forsaavidt deri maatte ligge noget Paafaldende, tildeels idetmindste lader sig betegne enten ved en simpel Anmærkning eller i fornødent Fald ved Administrators og Retsvidners Skjøn; og endelig, at det ligesaa fra Areopagos's Tid er en bekjendt Erfaring, at Angjældende Egenskaber, saasom Skjønhed, Veltalenhed, Forstilleleskunst m.m., ere istand til at bestikke Dommerenes Fasthed og Dømmekraft, hvilken Fare ligeledes maa lægges paa Vægtskaalen, naar der spørges om de Bevismidlers Værd, der ikke lade sig protokollere.. ${ }^{58}$

Videre burde faktum i saken ikke vurderes av en jury, mente kommisjonen, fordi - som vist ovenfor allmennhetens dannelsesnivå foreløpig lå for lavt. Endelig burde heller ikke bevisbedømmelsen være fri, særlig ikke i kombinasjon med en prosessmodell basert på bevismuntlighet, fordi bevisets vekt da ville avgjøres etter

58 Prosesslovkommisjonen av 1853, Om Forandringer $i$ Straffeproceslovgivningen med eller uden Jury. Betcenkning. Andet Bind, Første Deel, Christiania 1856, s. 22. 
«et Totalindtryk af en Mængde Omstændigheder, der ikke hver for sig lade sig fastholde eller betegne, saasom Angjældendes og Vidners optræden, og den Charakter, som derigjennem aabenbarer sig (Forslagenhed eller Aabenhed, Kløgt eller Sløvhed o.s.v.)». ${ }^{59}$

Problemet, ifølge Straffeprosesslovkommisjonen, var at under et slikt system ble alle ytre målestokker for vurdering av bevis fjernet fordi bruk av en objektiv målestokk forutsatte at «Beviset lader sig analysere i dets enkelte Bestanddele». ${ }^{60}$ Kommisjonen anbefalte derfor å opprettholde de gjeldende lovbestemte bevisregler. Dommernes bevisvurdering burde være bundet slik at en tiltalt bare kunne $\mathrm{d} ø$ mmes dersom bevisgrunnlaget etter forutbestemte regler holdt. ${ }^{61}$ Bindingen gjaldt imidlertid også den andre veien. Dommerne måtte dømme ved fullt bevis selv om de var overbevist om den tiltaltes uskyld, ifølge kommisjonen. ${ }^{62}$

Hvordan skal denne bindingsviljen forstås? Michalsen forklarer den med at legaliseringen ga domstolen en viss objektiv legitimitet og ensretting. ${ }^{63}$ Jeg har hevdet at dette kan forstås som et uttrykk for hva slags type feil det for dommerne var ansett som verst å begå - validitetsfeil som følge av at lovgivers regler var lite treffende operasjonalisert med tanke på temaet som skulle unders $\varnothing$ kes, eller reliabilitets- eller skjønnsfeil som følge av den enkelte dommers subjektive vurderinger. ${ }^{64}$ Kommisjonens argumentasjon kan også ha paralleller til Torstein Eckhoffs behandling av bevisbyrden i Tvilsrisikoen; spørsmålet er hvem som må bære ansvar for den nødvendige risikoen som følger av bevisbedømmelse overhodet. ${ }^{65}$ Kanskje kan dette også ses som en sekularisert utgave av den moralske angsten som rettshistorikeren James Whitman mener rammet dommere da straffedommer gikk fra å være betinget av gudgitte prøvelsers utfall til å være betinget av menneskelig vurdering. ${ }^{66}$

\footnotetext{
${ }^{59}$ Ibid., s. 235.

${ }^{60}$ Ibid.

${ }^{61}$ Ibid., s. 231.

${ }^{62}$ Ibid., se dog diskusjonen side 232-233.

${ }^{63}$ Dag Michalsen, Norsk rettstenkning etter 1800. tolv studier, Oslo 2013, s. 141.

${ }^{64}$ Lisbeth Fullu Skyberg, Rettslige forklaringers troverdighet: en teoretisk, historisk og empirisk unders $\phi$ kelse av bevismuntlighetens betydning for vurdering av troverdighet $i$ straffesaker, ph.d.-avhandling, Universitetet $\mathrm{i}$ Oslo 2019, s. 201.

${ }^{65}$ Ibid., se Torstein Eckhoff, Tvilsrisikoen, Oslo 1943, og dessuten Rt-1998-268 s. 275.

${ }^{66}$ James Whitman, The Origins of Reasonable Doubt, New Haven 2007.
} 
Prosesslovkommisjonen framførte imidlertid også et forsvar for den legale bevisbedømmelsen som går i motsatt retning. Slik legal bevisbedømmelse ble utøvd i Norge, innebar den, ifølge kommisjonen, større frihet for dommerne enn om de skulle være underlagt negativ bevisteori. Den legale bevislæren, illustrert f.eks. ved reglen i NL 1-13-1, om at fullt bevis dannes av to vitner «overensstemmende og udi een Ting» utgjorde ikke, ifølge kommisjonen, «for store Indgreb i Dommerens Frihed», fordi de gjennom indisiebeviset var gitt en stor grad av frihet. ${ }^{67}$

Slike indisiebevis ble jevnlig antatt ved domstolen, påpekte kommisjonen, slik at man i vår ordning kunne slutte analogisk fra hva loven uttalte seg om, til «hvad den rimeligvis maatte ville med hensyn til det, den ikke har udtalt sig om». ${ }^{68}$ Kommisjonen mente derfor at det hadde dannet seg en "praktisk Opfatning om de Fordringer, der bør gjøres ogsaa med hensyn til Indiciebeviset», men at denne fordringen ikke lot seg oppstille gjennom regler. ${ }^{69}$ Denne friheten var viktig fordi mens legale bevisregler ble sett som anvendelige for vurderinger av forbrytelsens «ydre Side», ble de ansett som mindre anvendelige for vurderingen av «Handlingens subjective» side. ${ }^{70}$ Dette var ikke minst ansett som viktig fordi det, som Pihlajamäki også påpeker, hadde vokst fram en endret begrunnelse for straff slik at det ikke bare var gjerningen, men også intensjonen bak forbrytelsen som hadde betydning for straffereaksjonen. ${ }^{71}$

Bevisvurderingen ble i det norske systemet dermed ikke bare avhengig av bevisbed $\varnothing$ mmernes indre stemme, men den indre stemmen var samtidig sikret plass. Systemer underlagt negativ bevisteori, som måtte forholde seg til spesifiserte minimumskrav for domfellelse, baserte seg imidlertid, ifølge kommisjonen, på «en Labyrint av Klasser og Afdelinger» som skulle fors $\varnothing$ ke å binde dommeren med detaljerte regler. ${ }^{72}$ Men med dette utsatte man seg bare for en like stor vilkårlighet som den man ville unngå, mente kommisjonen, fordi man førsøkte å etablere en matematikk for størrelser som prinsipielt var ubestemmelige.

${ }^{67}$ Prosesslovkommisjonen av 1853, Om Forandringer i Straffeproceslovgivningen med eller uden Jury. Betcenkning. Andet Bind, Første Deel, Christiania 1856, s. 245.

${ }^{68}$ Ibid., s. 234.

${ }^{69}$ Ibid.

${ }^{70}$ Ibid., s. 243.

${ }^{71}$ Heikki Pihlajamäki, Evidence, Crime, and the Legal profession. The Emergence of Free Evaluation of Evidence in the Finnish Nineteenth Century Criminal Procedure, Stockholm 1997, s. 128-130.

72 Prosesslovkommisjonen av 1853, Om Forandringer i Straffeproceslovgivningen med eller uden Jury. Betenkning. Andet Bind, Første Deel, Christiania 1856, s. 24. 


\section{Hva vant fram?}

I 1887 hadde imidlertid svaret på alle de tre ovennevnte spørsmålene endret seg fra nei til ja. Vi fikk en beslutningsmodell for straffesaker som var bygget rundt prinsippene om fri bevisbedømmelse, bevismuntlighet, jury og offentlig anklageprosess. Denne modellen $n ø$ dvendiggjorde avskaffelsen av det som til da hadde blitt betraktet som den viktigste rettssikkerhetsgarantien: appellen eller anken. Med en skriftlig prosessordning kunne bevisene i en sak, nedtegnet som de var i skriftlige akter, følge saken fra en instans til en annen. Men dersom en muntlig bevisførsel skulle gjentas for en appellinstans, ville det ikke lenger egentlig være snakk om en appell, sa Jurykommisjonen, men om en ny førstegangsbehandling for en annen domstol. «Og om at tilstaa en Part ubetinget Adgang hertil kan der selvfølgelig ikke være Tale. ${ }^{73}$ Kommisjonen begrunnet sitt standpunkt både $\varnothing$ konomisk og epistemologisk. Dels ville en ordning med ny førstegangsbehandling av en allerede behandlet sak være for kostbar. Dels var det grunn til å tro at bevisene ville forringes mellom første og annen gangs behandling. Forårsaket av tiden som gikk mellom rettsbehandlingene, ville vitnemålene måtte bli mer usikre, og risikoen $\varnothing$ ke for at vitner falt bort.

Appellens sentrale status som rettssikkerhetsinstitutt før 1887 hadde vært begrunnet med domstolens og befolkningens behov for at rettsavgjørelser var basert på en riktig vurdering av faktum og en riktig forståelse av jussen. I den nye ordningen som juryloven innførte, skulle det riktignok fortsatt være mulig å anke over prosessuelle feil, og en straffesak kunne også komme opp for ny behandling dersom senere omstendigheter viste at det var blitt gjort «Feiltagelser mot Realiteten». ${ }^{74}$ Men i normale tilfeller ville faktum i de alvorligste straffesakene etter 1887-loven kun gis én vurdering. Jurykommisjonen gjorde det derfor også klart at «[n]aar Mundtligheden saaledes $n \emptyset$ dvendiggjør Appellens afskaffelse, saa krever den til Gjengjæld et desto paalideligere Grundlag for Afgjørelsen i første Instants og desto fuldkommere Organisation af denne Domstol». ${ }^{75}$ De rettssikkerhetsmessige ulempene som avskaffelsen av appellen skapte, ser slik ut til å ha blitt vurdert som oppveiet av den nye beslutningsmodellens organisering. Kommisjonen hevdet at det som krevdes, i tillegg til fri bevisbedømmelse, var «en kollegial Ræt med fuld offentlig og umidddelbar Anklageproces, og til Opnåelse deraf kræves igjen, som i næste Stykke skal vises, Lægmænds

\footnotetext{
${ }^{73}$ Jurykommisjonen av 1885, Dokument No 1. Indstilling fra Jurykommisionen indeholdende Udkast til Lov, s. 491.

${ }^{74}$ Ibid.

${ }^{75}$ Ibid.
} 
Deltagelse; der kræves Jurydomstole».$^{76}$ Denne ordningen ble da også stående i over 100 år, fram til innføringen av to-instansordningen muliggjorde at også de alvorligste sakene kunne få to behandlinger av faktum.

\section{Hvor fullkommen var modellen?}

Sett fra fagpsykologien innebærer også den norske modellen klare svakheter. Det er likevel interessant at det rettsprinsippet som juristene har vært mest bekymret for at skal true rettssikkerheten, nemlig prinsippene om lekmannsdeltakelse, ikke er blant prinsippene som har fått mest kritisk oppmerksomhet av psykologene. Fagpsykologien har fremmet særlig to kritikker, og den første angår prinsippet om bevismuntlighet.

En sentral begrunnelse for direkte bevisførsel har siden innføringen av prinsippet vært at den gjør dommernes troverdighetsvurderinger mer treffsikre, i Jo Hovs lærebok i prosess spissformulert i uttalelsen «papir rødmer ikke, er det sagt». ${ }^{77}$ Ifølge psykologien virker imidlertid ikke det utvidede informasjonsgrunnlaget som bevismuntligheten gir dommerne, på denne måten. Riktignok finnes det verken vokale, verbale eller visuelle ledetråder som fungerer som diagnostiske tegn på om noen lyver eller snakker sant. Men psykologen Aldert Vrij viser i sin internasjonalt anerkjente oversiktsbok i løgnpsykologi til at jo flere visuelle ledetråder folk oppgir at de benytter i sine vurderinger av troverdighet, jo lavere treffsikkerhet har de. ${ }^{78}$

Den andre kritikken er rettet mot prinsippet om fri bevisbedømmelse. Dualistisk beslutningsteori har vist at rasjonaliteten er en begrenset ressurs, og at beslutningene våre er sårbare for en rekke beslutningsskjevheter. ${ }^{79}$ Disse sårbarhetene rammer imidlertid ekspertskjønn i like stor grad som lekmannsskjønn så lenge skjønnsutøvelsen ikke er regulert av en bestemt og tvingende metode. Fri

\footnotetext{
${ }^{76}$ Ibid.

77 Jo Hov, Hov, Rettergang II, ny utg., Oslo 2010, s. 125.

${ }^{78}$ Aldert Vrij (2015), Detecting Lies and Deceit. Pitfalls and Opportunities. 2. Ed. Chichester, s. 173.

${ }^{79}$ For en introduksjon, se Daniel Kahneman, Tenke fort og langsomt, Oslo 2012.
} 
bevisbedømmelse framstår slik som et godt eksempel på det som i kognitiv teori kalles beslutningstaking under usikkerhet. ${ }^{80}$

Med utgangspunkt i Løvlies innledende sitat kan vi si at bevismuntligheten utvider kategorien av hva som får lov til å vise til noe annet som bevis. Men denne utvidelsen av datagrunnlaget for dommernes vurderinger innebærer ifølge psykologisk forskning et stort rom for feiltolkninger. De norske vitnepsykologene Svein Magnussen og Annika Melinder har uttalt at «moderne forskning $\mathrm{i}$ kognitiv psykologi og sosialpsykologi viser at antatt rasjonelle sosiale vurderinger er påvirket av irrasjonelle faktorer», og at «slike faktorer slår sterkest ut i direkte møte med andre mennesker». ${ }^{81}$ Dette bidrar til, påpeker de, at «[v]urderinger hvor retten konfronteres ansikt-til-ansikt med tiltalte, fornærmede og vitner, er spesielt sårbare for irrasjonelle påvirkninger». ${ }^{82}$

Advarselen har klare likhetstrekk med den som ble framført av Straffeprosesslovkommisjonen nedsatt i 1853, og som - som vi har sett - avviste bevismuntlighet blant annet med begrunnelsen at dette datagrunnlaget «ere i stand til at bestikke Dommerens Fasthed og Dømmekraft». ${ }^{83}$ Det er slik en gammel og internjuridisk bekymring fagpsykologien i dag igjen løfter fram.

Den psykologiske kritikken av den straffeprosessuelle, sannhetsproduserende motoren kan kanskje slik metaforisk oppsummeres ved at ingen foreløpig har klart å lage den til en turbomodell? En turbo, eller turbin-booster, sitter i eksosanlegget og er drevet av at avgassene motoren produserer, tilbakeføres på en måte som skaper større effektivitet i forbrenningsmotoren. En slik turboeffekt, i en straffeprosessuell sammenheng, måtte innebære at «avfallsstoffene» fra bevisvurderingen kunne tilbakeføres til systemet slik at sannhetssøkingen motoren skal generere, blir mer effektiv. Dette ville imidlertid kreve at dommerne får raske tilbakemeldinger om egne feil. ${ }^{84}$ Fordi den

\footnotetext{
${ }^{80}$ Lisbeth Fullu Skyberg, Rettslige forklaringers troverdighet: en teoretisk, historisk og empirisk unders $\phi k e l s e$ av bevismuntlighetens betydning for vurdering av troverdighet $i$ straffesaker, ph.d.-avhandling, Universitetet $\mathrm{i}$ Oslo 2019, s. 7, se også kapittel 3, 7 og 14.

${ }^{81}$ Svein Magnussen og Annika Melinder, «Umiddelbarhetsprinsippet i bevisvurdering - en utfordring for rettssikkerheten?», Lov og Rett 2014, nr. 10, s. 607-621, s. 607.

82 Ibid.

83 Prosesslovkommisjonen av 1853, Om Forandringer $i$ Straffeproceslovgivningen med eller uden Jury. Betcenkning. Andet Bind, Forste Deel, Christiania 1856, s. 22.

${ }^{84}$ Se f.eks. Daniel Kahneman og Gary Klein, «Conditions for intuitive expertise: A failure to disagree», American Psychologist 2009, vol. 64, issue 6, s. 315-325 - http://dx.doi.org/10.1037/a0016755 (2009); Christian Diesen, «Juridiska perspektiv på bevisvärdering», i Pär Anders Granhag og Sven Å. Christianson (red.),
} 
straffeprosessuelle beslutningsmodellen gir små muligheter for dommerne til å undersøke den objektive riktigheten av egne foretatte vurderinger, utover deres egen overbevisning om at de i det enkelte tilfelle har vurdert riktig, er en slik kunnskapsmessig «feedback loop» vanskelig å få til.

Handbok i rättspsykologi, Stockholm 2008; Geir Kirkebøen, «Når er fagfolks intuisjon til å stole på?», Psykologisk.no, 2014 - https://psykologisk.no/2014/02/nar-er-fagfolks-intuisjoner-til-a-stole-pa/ 